University of Nebraska - Lincoln

DigitalCommons@University of Nebraska - Lincoln

University of Nebraska Press -- Sample Books

and Chapters

University of Nebraska Press

2013

Finding the Woman Who Didn't Exist

Melanie . C. Hawthorne

Follow this and additional works at: https://digitalcommons.unl.edu/unpresssamples

Hawthorne, Melanie . C., "Finding the Woman Who Didn't Exist" (2013). University of Nebraska Press -Sample Books and Chapters. 156.

https://digitalcommons.unl.edu/unpresssamples/156

This Article is brought to you for free and open access by the University of Nebraska Press at DigitalCommons@University of Nebraska - Lincoln. It has been accepted for inclusion in University of Nebraska Press -- Sample Books and Chapters by an authorized administrator of DigitalCommons@University of Nebraska - Lincoln. 
Finding the Woman Who Didn't Exist 
Buy the Book 


\section{Finding the Woman Who Didn't Exist}

\section{The Curious Life of G I S È LE D'E S T O C}

Melanie C. Hawthorne

UNIVERSITY OF NEBRASKA PRESS - LINCOLN AND LONDON 
(C) 2013 by the Board of Regents of the University of Nebraska. An earlier version of chapter 4 first appeared as "Gisèle d'Estoc: Portraits of a Decadent Woman," Nordlit 28 (2OII) : 223-44. All rights reserved. Manufactured in the United States of America.

(9)

Library of Congress Cataloging-in-Publication Data

Hawthorne, Melanie.

Finding the woman who didn't exist : the curious life of Gisèle d'Estoc / Melanie

C. Hawthorne.

p. cm.

Includes bibliographical references.

ISBN 978-0-8032-4034-6 (cloth : alk. paper) I. Estoc, Gisèle d', I863-ca. I906.

2. Women authors, French — I9th century—Biography. 3. Women sculptors-

France — I9th century-Biography. 4. Bisexual women-France-Biography.

5. Male impersonators-Biography. 6. Women anarchists-France-19th century-

Biography. I. Title. II. Title: Curious life of Gisèle d'Estoc.

PQ2240.E76Z65 2013

$843^{\prime} .8-\mathrm{dc} 23 \quad 2012032678$

Set in Monotype Fournier Pro by Laura Wellington. Designed by A. Shahan. 
To Eunice Mahoney, who has been such an inspiration 
Buy the Book 


\section{Contents}

List of Illustrations viii

Acknowledgments ix

Introduction I

I. To Hell and Back (the Present) I5

2. Gisèle d'Estoc and World War II (the I930s) 35

3. A Storm in a Teacup and a Bomb in a Flowerpot (the I890s) 53

4. An Interlude (No Time in Particular) 79

5. Gisèle d'Estoc When She Was Real (the I870s) I05

6. Gisèle d'Estoc and Who She Wasn't (the I96os) I3I

Afterword 159

Chronology $\quad 167$

Notes $\quad$ I 73

Works Cited 195 


\section{Illustrations}

I. Trees in cages outside the Bibliothèque nationale de France

2. A police reconstruction of how the Foyot restaurant bomb must have been made 57

3. Gisèle d'Estoc in her schoolboy costume $7 \mathrm{I}$

4. Emile Bayard's Une affaire d'honneur 82

5. Maupassant playing tennis 92

6. Emile Bayard's Réconciliation 97

7. Portrait of d'Estoc by Henri Louyot from i89I IOI

8. Rue Herran, where d'Estoc lived in I880 Io9

9. I rue de Tocqueville, where d'Estoc was living in I885 II I

IO. A bust of a peasant woman from Lorraine II2

II. The corner of the rue St. Honoré and the place Vendôme II8

I2. D’Estoc and her friend Marie Edmée Pau I44

I3. Birth certificate of Marie Paule Courbe I5 I

I4. Courbe family tree $\quad \mathrm{I}_{52}$ 


\section{Acknowledgments}

This book was a long time in the making, and along the way I have accumulated many debts. There are many people to thank, and some are acknowledged in notes to the text, but special mention must be made of Christian Laucou, who was one of the first people to set me thinking about the enigma that was Gisèle d'Estoc. I also had help along the way from Philippe Oriol, Gilles Picq, and Richard Shryock. Eleanor Albert helped out with some photos, Cheryl Morgan put me up (and put up with me), and Lynn Higgins introduced me to my dedicatee. Several units at Texas A\&M University supported the research that made this book possible, including the Department of European and Classical Languages and Cultures, the Office of the Dean of Liberal Arts, and the Glasscock Center for Humanities Research. Parts of the book were presented as work in progress at scholarly conferences such as the NineteenthCentury French Studies Colloquium and the Workshop on Cultural Production in Nineteenth-Century France at the University of Florida Paris Research Center, and I am grateful to those communities of scholars in general for their support and interest. Many librarians and archivists smoothed the way for me, including J. Fernando Peña, curator of collections at the Grolier Club in New York. As always, I owe a huge debt to the members of my writing group: I hope this will be an addition to the collective $\mathrm{cv}$ that you will be proud to share credit for. And I owe a special thank you to Mathilde Huet, someone I am now pleased to call a friend, who shared so generously her own research. As for the title? Thanks, Patty! 
Buy the Book 
Finding the Woman Who Didn't Exist 
Buy the Book 


\section{Introduction}

This is a book about Gisèle d'Estoc. If you have never heard of her, you are not alone, and you may be wondering (to paraphrase the Victorian "nonsense" poet Edward Lear) who, or why, or which, or what is Gisèle d'Estoc? ${ }^{1}$ This book offers some answers to these questions. The short version is this. First of all, the answer to the question "What is Gisèle d'Estoc?" is that it is a pseudonym, but resolving this question only gives rise to another one: "Then who is she?" That is the question some people have been asking for over a century, as they tried to identify the person behind the mask once and for all. You will find out in the course of this book why people cared about finding her, and you will discover that we now know that she was really Marie Paule Alice Courbe (1845-94), who rubbed shoulders with the famous and not so famous of fin-de-siècle France, and who tried her hand at creative endeavors of her own (mainly as an artist and writer). But I am getting ahead of myself by telling you the answer to the riddle of her identity. In fact, we haven't always been sure who she was; that is, we didn't always know that she was Marie Paule Alice Courbe. As this book makes clear, for a long time the person known as Gisèle d'Estoc was confused with another person, so that there were several theories, not always compatible, about her true identity for quite a while. So the deceptively simple question of who is Gisèle d'Estoc in fact resolved itself into the more complex question: "Which (one) was Gisèle d'Estoc?" I hope that by the time you finish reading this book, you will agree that the correct answer is that she was indeed Marie Paule Alice Courbe, and you will understand why other identifications have been rejected even though they 
seemed compelling at the time they were articulated. Finally, then, there is the question, "Why Gisèle d'Estoc?" Why bother searching for someone who seems to have disappeared from history without being missed? Why write the biography of a nobody?

The enterprise of writing the lives of others, or biography, has been around for centuries, but who merits such attention is a concept that has changed over time, reflecting broader cultural assumptions. ${ }^{2}$ Those at the helm of society - monarchs, emperors, great statesmen (and they were nearly always men), military leaders-have always been obvious candidates for study because of the impact of their actions on everyone's life. The educated (and sometimes not-so-educated) public was interested in the accomplishments of such people and the forces that shaped them and that they in turn helped shape. Similarly, religious figures such as saints were commemorated in hagiography because their virtuous lives served as an example (or exemplum) to others. One of the earliest texts in the language we now call French was written to praise a good girl called Eulalia who became a saint ("bona puella fuit Eulalia ..."). But these historical and religious people were exceptional, inspirational. While we might aspire to be like them, we knew we were unlikely to match their attainments, and what was interesting about them was their being such exceptions. Although the subject of modern biography has expanded to include artists and writers as well as popular musicians and film stars (the saints of contemporary society, perhaps), we still essentially think of these people as somehow different from the rest of us (no matter how much we might want to imitate them), and their interest lies in this difference.

In the last century or so, the democratic impulse to assert that everyone is equal has legitimized a widening of scope in the biographical enterprise. The belief that leaders were set apart from commoners by different blood or divine choice has ceded to the notion that we are all made of the same stuff, more or less, and that each has a part to play. ${ }^{3}$ The exceptional and celebrated will always have their place, but we are increasingly interested in others like us. What was it like to be

\section{Introduction}


an ordinary, unexceptional person at different times and in different places? What was it like to be the kind of person we are more likely to identify with or to have among our ancestors? Now, we are interested in the life of the typical as well as that of the unique. The life of a nobody no longer seems so devoid of interest, but there remains a need to articulate why this nobody as opposed to that one should command our attention. Some recent biographies of what we might call unexceptional people illustrate the genre and its raisons d'être. The life of Elizabeth Marsh (1735-85) was not particularly remarkable in and of itself. True, she was captured by pirates and confined in a harem, and she lived to tell the tale and even publish a narrative of her experience, but in most respects one can say that she lived and died without leaving much of a mark on the world. Yet in the hands of a skilled historian and storyteller such as Linda Colley, the story of Elizabeth Marsh becomes a paradigm for demonstrating that globalization - which we think of as a recent phenomenon - was already well under way in the eighteenth century. Colley's book The Ordeal of Elizabeth Marsh: A Woman in World History has also been credited with establishing a new genre of biography, the economic biography, in which the life story of a person shows the way international trade and finance evolved around the globe. ${ }^{4}$

Then there is the case of the social outcast who occupies a marginal place in society, the kind of homeless panhandler who is a common sight on urban streets. Most of us would like to think that we need not identify with such a person, but a fear lingers that he is more like us than we might care to acknowledge, that but for the grace of God (or some other set of circumstances that, precisely, we hope to learn more about from the biographical enterprise) we might in fact have a great deal in common with such a person, even as we hope to be spared his fate. Alexander Masters shows us one such person in Stuart: A Life Backwards, turning the abject loser into a subject who wins us over by making us care about how a fellow human being (and therefore implicitly any one of us) could be brought so low. To do so, Masters tells the life in reverse, beginning with Stuart's present (adult) condition and working backward to show how it came 
about. The early life of an unremarkable person thereby takes on a new interest when we see it as the explanation of how later events that we are already familiar with came about. This is true in the celebrity biography, too, of course. We care about the early years because we already know how Marilyn Monroe turned out later. But in the case of an otherwise unknown person, we need to know early on what is at stake when we invest in the narrative. What is the payoff for caring?

French historians and biographers such as Alain Corbin and Gillian Tindall have pursued accounts of a specifically French Everyman (though again, these are ordinary men, not women), particularly those from the nineteenth century, a time far enough removed to be forgotten but not so far that all records have been lost. Corbin plucks someone - Louis-François Pinagot (I798-I876) — virtually at random from the archives purely as an exercise in seeing just how much can be discovered from such records and other sources about a person who did not distinguish himself in any public way. Pinagot is, as Corbin puts it, "un pauvre sabotier qui a vécu, toute sa vie, dans la région la plus misérable d'un des départements les plus déshérités de France" (a poor clog maker who lived his whole life in the most wretched region of one of the most deprived départements of France) $(225){ }^{5}$ In addition to basic information culled from censuses and the état civil, from court papers and army conscriptions, Corbin extrapolates from information about how different kinds of clogs were made, and from what we know about the wages and conditions of spinners and glove makers in general in order to build up a picture of Pinagot's life. The re-creation asks us, among other things, to imagine what it must have been like to be a single parent fined the equivalent of two weeks' pay ( 5.70 francs) for the crime of having stolen some wood to keep warm, or to lose what might be an entire week's income (2.20 francs) for stealing branches from a tree felled by snow (I42). ${ }^{6}$ As I write this, it is 46 degrees Fahrenheit outside, and I shiver at the thought of what it would mean to rely on wood that I must find and collect myself every day to stay warm, especially if I could harvest

\section{Introduction}


only what grew on land that belonged to me. There is no evidence to suggest that anyone in Pinagot's world thought such a fine (half a month's income) excessive or unusual, no mention of collective protest or social movement of discontent - and more chilling than the reminder of what it means to be without central heating is the realization that, had I been part of this "lost world" (Corbin's term), I, too, would probably have found such justice meet. In some ways, I rejoice that such a cold world is now lost, even as I suspect that it is not remote enough, but I need the biography of Pinagot to be reminded of the comforts I take for granted.

Becoming nothing but a name in the archive like Louis-François Pinagot is a fate we all might share eventually, but Corbin reassures that no matter how ephemeral our own particular life might be, no matter how quickly the tide of time comes in and washes the sight of our footprints from the sandy shores of memory, we are not entirely lost to future history (so long as historical records survive). Gillian Tindall explores a case of one whose footprints we no longer see, though reassuringly he proves far from lost to us. Her subject, Martin Nadaud (I8I5-98), was a mason from the Limousin who became the first working-class member of the French parliament. Not quite a nobody, then, but at the same time not enough of a somebody to be widely and easily recalled. Tindall is so perturbed by the fact that no one seems to remember Nadaud that "once or twice in the night" she wonders if he really existed or if she "had somehow invented him" ( $\mathrm{I} 6$ ). But she knows better, and the cold light of day provides plenty of evidence of his existence and impact. With the help of public records that offer documentation about the public person, Tindall also re-creates the private person, the ordinary man who started out as a typical humble mason from the provinces who took part in the annual migration to Paris in search of work in the building trade.

Biography has also been inspired by the feminist movements of the twentieth century to pay closer attention to the experiences of women and to the role of gender in shaping lives. In part this corrective 
came about because the assumption that "women are just like men only different" has been challenged by discoveries in many domains that suggest that the paradigm in fact looks quite different. This is no less true of biography than of other fields. Accounts of women's lives have raised important questions about the enterprise of biography itself: about what "belongs" in the story of a life; about the distinction between public and private; about how to evaluate nontraditional sources of information such as hearsay and gossip, which are sometimes the only places information remains about what happened to those were overlooked in their own lifetime; and about the many ethical issues raised when a person starts telling stories about someone else's life. A pioneer in the field of women's biography, Carolyn Heilbrun, famously described in Writing a Woman's Life how the trajectory of life stages can look different in the lives of men and women; for the latter, aging can bring increased rather than diminished power, as younger women are used to having to watch what they say when dependent on others. In her biography of Eleanor Roosevelt, Blanche Wiesen Cook had to decide whether omitting what she discovered about her subject's affective and sexual preferences was a form of discretion or of distortion (she chose the latter and broke a long-standing tradition of silence about Roosevelt's private life). Ethical issues can take many forms, especially as biography itself can be seen as a dubious undertaking, characterized (humorously) by Mina Curtiss as stemming from a somewhat unhealthy desire to read other people's letters. ${ }^{7}$ Diane Middlebrook's groundbreaking biography of the poet Anne Sexton benefited from Middlebrook's access to records kept by her subject's therapist, but her decision to use that normally confidential material was not without controversy. In pursuing information about the lives of women writers who had not been thought to merit much attention during their own lifetime, Emily Toth has confronted the tricky issue of how much weight to give to gossip and rumor in her biographies of Kate Chopin and Grace Metalious (quite a lot, she suggests). Other biographers have had to consider the ethical implications of having intimate relations (or not) with sources whose information might be compromised or

\section{Introduction}


withheld as a result of the choice. ${ }^{8}$ Nor are these kinds of issues confined to the sometimes "puritan" Anglo-Saxon world. In France, recent biographies of well-known and much-loved authors that delve into previously untold stories have shaken up the way popular authors such as Colette and Simone de Beauvoir are seen."

Being a little too interested in "other people's letters" is only the beginning of the exploration of what motivates biographers, and here, too, women have been at the forefront of a movement to understand the personal, sometimes hidden, often underestimated or overlooked stakes that drive the author. One of the most outstanding examples in this subfield of the genre is surely Eunice Lipton's Alias Olympia, in which her search for impressionist Edouard Manet's model Victorine Meurent is intertwined with autobiographical reflection and analysis. Opinion about this approach is divided, with some praising and others deploring this foregrounding of the author's persona, but whatever the verdict, Lipton is to be credited with drawing attention to the fiction of authorial objectivity in biography. Her creative approach has been much emulated, not always as successfully, it must be said, but often with interesting results. Recent examples in this genre include Ann Wroe's Being Shelley and Maria diBattista's Imagining Virginia Woolf. Some of these contributions have been in the field of French studies, with efforts that range from Michele Zackheim's novel Violette's Embrace, in which the narrator describes her discovery of the writer Violette Leduc, to the more scholarly example of Janet Beizer's recent analysis of how the biographer may want so badly to discover the words of her subject that she (sometimes inadvertently) supplies them herself, filling silences with her own ventriloquized voice rather than allowing the silences to remain. Such different approaches have fostered what might be called a "nonlinear" approach to biography — that is to say, ways of recounting a life that don't follow strict chronological order. It is an approach I explore in this book, too. Here, the story of Gisèle d'Estoc's life begins long after her death, with a rumor that she was only a hoax, that she had never really existed. From this starting point, I trace the attempts to prove her existence and to establish her true identity, with

Introduction 7 
the story of her birth — normally the starting point of a life — coming only at the end of the narrative. Along the way, I hope to show why this life, despite the difficulty of apprehending it, is so compelling as to make literary historians keep worrying at the knots it offers.

For the proliferation of biographies of women has also resulted from the fact that so many fascinating lives have been overlooked. How could the story of a woman who cross-dressed and lived as a man in order to pursue a career in the male-dominated field of jazz music fail to be interesting? In the hands of a superb biographer such as Diane Middlebrook, the subject is not merely interesting, it is absolutely compelling, and Suits $M e$, her life of Billy Tipton, is an example of the heights that good biography can attain. Thanks to the injection of gender as a factor in biography — both the comingof-age of a generation of talented women biographers and the creation of a reading public interested in women's lives - the last part of the twentieth century was marked by an explosion of outstanding biographies of women, including works by Deirdre Bair (Simone de Beauvoir), Victoria Glendinning (Vita Sackville-West), Lyndall Gordon (Charlotte Brontë, Emily Dickinson, Mary Wollstonecraft, Virginia Woolf), Kathryn Hughes (George Eliot and Mrs. Beeton of cookbook fame), Hermione Lee (Edith Wharton, Virginia Woolf, Willa Cather), Brenda Maddox (George Eliot, Nora Joyce, Rosalind Franklin), Janet Malcolm (Gertrude Stein and Alice Toklas, Sylvia Plath), Diana Souhami (Gertrude Stein and Alice Toklas, the artist known as Gluck, Violet Trefusis, Radclyffe Hall, Natalie Barney and Romaine Brooks, among others), Hilary Spurling (Ivy ComptonBurnett, Pearl Buck), and Claire Tomalin (Katherine Mansfield, Mary Wollstonecraft).

The story of Gisèle d'Estoc, or Marie Paule Alice Courbe, takes its place alongside these narratives. Her life, as I hope to show, was not without interest in its own right (like Nadaud's), but it also offers insight into the roles and accomplishments of women in a time and place where we often assume they are far more circumscribed than they apparently were. Women may have faced many limitations in nineteenth-century France, but not everyone played by the

\section{Introduction}


rules and Gisèle d'Estoc seems to have broken most of them at one time or another in her colorful life. She was not the typical French woman of her time, hardly an Everywoman, except in the sense that she was not born to riches or greatness but had a go at seizing them with her own two hands all the same, as it is given to all of us in some way to make a similar effort and see where it lands us. D'Estoc pursued her art to the point of exhibiting at the Paris Salon. She took up both the sword and the pen (and this book will have something to say about the relationship between those two artifacts). She disguised herself as a schoolboy and took both men and women as lovers (and yes, sometimes disguised herself in order to do so). And if, finally, she was not the anarchist bomber she was believed by some to be (as I shall argue), the fact that the accusation was credible testifies to her reputation for action and conflict.

Despite these attributes, d'Estoc represents the ordinary in that her real name is all but forgotten today. Thus, the story of Gisèle d'Estoc is a fascinating exercise in resurrection, an illustration à la Corbin of what can be discovered about a particular existence from records that have lasted more than a century after the disappearance of the person. ${ }^{10}$ That these records endure is a testimony to the humble mayors, clerks, and other minor state officials who did their job and carried out their duties; that the records can still be located in the face not only of benign neglect but of denial amounting to almost willful suppression is cause for optimism. Reanimating Gisèle also provides a pretext for bringing back to life the daily reality of Paris more than a century ago, an exercise in microhistory that echoes the work of Tindall at its best. ${ }^{11}$ And, like Linda Colley, I hope to suggest that the life of an otherwise mediocre person can illuminate broader trends at work in the period under consideration (which we will inevitably compare to our own day). We know a great deal about the circumscribed existence of the average nineteenth-century bourgeois French woman, the wife and mother who suffered and was still, ${ }^{12}$ and we know there were also pioneering exceptions who broke down the doors to institutions of learning, to professional enclaves, and to political houses, but Gisèle d'Estoc shows the ways these paths criss- 
crossed, rather than running along parallel lines. The accomplishments of the famous were facilitated by the minor infractions of the forgotten, and the path of the respectable middle-class woman was perhaps not always as straight and narrow as the history manual can acknowledge.

The sheer improbability of d'Estoc's life also connects this biography to the impish work of Spanish novelist Javier Marías, who delights in exhuming lives (or aspects of lives) that are so bizarre, his readers often conclude (wrongly) that he has invented them (I). As we shall see, readers have sometimes reached similar conclusions about d'Estoc, who would be a good candidate for one of Marías's "unique tales" (the title - in translation — of the original Spanish anthology that inspired his Written Lives), though my purpose here is to demonstrate that she did exist rather than perpetuate the doubt about her.

It is, finally, the process of rediscovering the existence of Gisèle d'Estoc against the odds that provides the most important justification for this book. In retelling the story of this exhumation from the dead (or at least the disappeared), I have two goals. The first is to demystify aspects of research practices in the humanities. What do people do in libraries and archives and why do they do it? In part, I want to show that archival research is not a matter of waiting for divine inspiration that provides clear and coherent answers that spring from the mind onto the page ready formed. Indeed, often, the researcher does not even know what the questions are. Research is frequently a messy business, more like a fishing expedition subject to all the vagaries of chance that determine what will land in the net. But chance (like the odds of landing the big one) can be shaped, wrangled, and sometimes tamed by intellectual effort, and the other part of what I want to demonstrate is that successful research involves real work: intellectual work, to be sure (involving complex thought and mental application), but work in the sense of effort nonetheless (and sometimes physical effort, as the next chapter will show). It's not rocket science, though as I shall argue in the final chapter it shares some 
properties with that, but it's not magic either. Humanities research involves skills, skills that can be formalized (up to a point), taught and transmitted, and applied to fields both within and without the humanities per se. These skills are what people refer to when they talk about critical thinking. Critical thinking is a valuable aspect of the humanities, and why they are worth preserving and teaching, both because such thinking skills are valuable in themselves and because they can be applied in other fields. In the competition for resources that often pits the humanities against other intellectual endeavors (rocket science, but also biomedical research, social science, and just about anything else), the humanities sometimes seem to suffer from the comparison. Other fields lead to applications that cure illness, prolong life, and — not to be underestimated — keep us warm in winter. Just how warm will a good book keep you (unless you burn it)? Humanities research often feels like the luxury, the extra that you can afford once you have taken care of the basics, the fancy wallpaper in the house of intellectual effort. Why worry about the wallpaper if the walls and other fundamental structures are not sound? This book offers two answers. The first is a pedagogical answer: the same intellectual processes are at work no matter what the discipline, and training in the humanities offers a good and practical way to acquire them.

The second is more of an ontological argument: Why do we want so desperately to prolong life? What are we living for, exactly? What's the point of staying healthy (and warm), or living a long life? One reason is to contribute in turn to the health and longevity of others, but even then, one has to have something to do of an evening after a long day in the lab. Einstein played the violin. The humanities offer consolation. No matter how well we may succeed in prolonging life (our own as well as that of others), being human remains a terminal condition, and we will always need comforting - or seek distraction - whenever we confront that fact. The reason the humanities were so valuable to our ancestors, the reason they invested so much time in these activities, even though their lives were so much shorter, uncertain, and filled with pain than ours - indeed,

Introduction II 
precisely because this was the case - is that good stories are either enlightening or entertaining, and sometimes both. Whether you are wracked with pain or blissfully comfortable, you must have something to do to pass the time, since passing time is what, as human beings, we are condemned to do. Whether you are waiting for God or Godot, as Samuel Beckett helps us to see, life is both a joy and a trial, something we are constantly being forced to experience. You can try to stay busy or you can distract yourself with television, but every now and again the angel of history pays a visit to remind you we are all being propelled into a future we cannot see while being forced to watch the disasters that pile up behind us that we cannot fix, as though experiencing life through the rear window of a car when you were a child (in the days before seat belts) except that now you are expected to drive blindly at the same time. In these exhilarating, terrible conditions, a good story provides a viable alternative to hibernating and thus spending even more of our always-too-short lives unconscious (more than the third we already spend asleep). For no matter how long a life is, it is somehow never quite long enough. I believe that the humanities will continue to be of very practical use to a large number of people who, when all is said and done, still want something to occupy their thoughts. Although that is not an impact that lends itself to measurement, its pull can be felt just as surely as the forces of gravity.

Structurally, as stated above, this is a backward book in that I tell the story of Gisèle d'Estoc's life in reverse order. After an opening chapter that introduces "the story of the story" and explains the value of approaching biography in a self-consciously metabiographical way, chapters 2 and 3 take on the question of whether Gisèle d'Estoc ever really existed, a question that has dogged the search for d'Estoc since the I930s. This debate began long after d'Estoc's death, on the eve of World War II, when the received wisdom was that she was no more than a hoax. Chapter 3 , however, shows how confirmation of d'Estoc's existence may be found in contemporary newspaper accounts of anarchist attacks in Paris in the I890s. The press coverage 
leads to the location of d'Estoc's death certificate, a chronological end point that becomes the starting point for the biography itself. D'Estoc became embroiled in conflict through her literary involvement, and so this chapter also recounts how she entered literary circles through her affair with the writer Guy de Maupassant in the i88os.

Having established d'Estoc's existence, there follows an interlude that steps away from the trajectory of the (reverse) chronological narrative to consider what we know of what d'Estoc looked like. There are many surviving photos and other representations of her, but chapter 4 playfully considers that there is more to how she is depicted than just what she looked like.

Returning to the biographical narrative, chapters 5 and 6 deal with who d'Estoc really was and the controversy surrounding her identification. D'Estoc's ties to the visual arts are tracked in chapter 5, which traces her own career as an artist. She exhibited both under her married name (Madame Desbarres) and her unmarried name (Marie Paule Courbe), a double life that creates its own set of confusions, but the greatest confusion about her identity has stemmed from trying to establish her date of birth in her home town of Nancy (in Lorraine, eastern France), a story retold in chapter 6 that assesses both who she was and who she wasn't. An afterword suggests that although this may be the end of the book, the story of Gisèle d'Estoc is far from over, and it returns to the theme of the lessons that can be learned from the enterprise of her biography. 